Open Access

\title{
Impact of seasonal climate change on optical and molecular properties of river water dissolved organic matter by HPLC-SEC and UV-vis spectroscopy

Viia Lepane*, Laura Depret, Anna-Liisa Väli and Kristel Suursööt

\begin{abstract}
Background: The change in the optical parameters of dissolved organic matter (DOM) from natural water samples of Pirita River in Estonia were studied during 2 years of winter-spring season. At present, the relative quantitative and qualitative composition of DOM components leached from soils to water, in relation to air and water temperatures and water level fluctuations, has not been estimated in Estonia. The aim was to characterise and fractionate DOM using high-performance size-exclusion chromatography with multiple wavelength detection (DAD) and ultraviolet-visible (UV-vis) spectroscopy. Changes in several chromatographic/molecular and spectroscopic/optical parameters were investigated.
\end{abstract}

Results: The experimental data indicated that the optical and molecular properties of DOM depend on the climate conditions, but the effect can be diverse. In cold climates, the concentration of DOM in river water can be lower (2013) or higher (2014) than in warmer climate conditions. Optical properties indicate that the quantity of humic substances (HS) is minimal under an ice cover and DOM contains more microbial-derived peptide-like constituents.

Conclusions: The results point out the usefulness of HPLC-SEC and UV-vis spectroscopy for climate change-related DOM studies in real environmental conditions. Used methods enable detailed monitoring of humic molecules dissolved from the catchment soil, as well as microbial constituents (peptide-like components of DOM). The used approach can be additionally applied for monitoring the changes of raw water quality and thus for the design and optimisation of drinking water process technology.

Keywords: DOM; HPLC-SEC; UV-vis spectroscopy; Absorbance ratios; Water; Climate

\section{Background}

Dissolved organic matter (DOM) forms most of the naturally occurring organic matter in water, and its influence on aquatic environments is enormous. Despite the important ecological role, there have been relatively few investigations on the impact of climate change on DOM constituents [1-6] and much is still uncertain about the structure, quality and properties. Organic carbon in soil and water has a great impact on the global carbon cycle [7]. Previously, the importance of organic matter was recognised as a possible indicator of climate change [8].

\footnotetext{
* Correspondence: viia.lepane@ttu.ee

Department of Chemistry, Tallinn University of Technology, Akadeemia tee 15, 12618 Tallinn, Estonia
}

A considerable part of soil organic matter can be dissolved during the seasonal climate changes because of the extensive floods and runoff, as well as because of the significant changes in the air and the water temperatures. A river with a large catchment area usually receives a considerable amount of soil-derived (usually named allochthonous) organic matter. The DOM, expressed as dissolved organic carbon (DOC) concentration, depends on many hydrological parameters that are highly variable, as noted in recent studies $[9,10]$. Increases in DOC concentrations in water are evident and observed in many countries, but the reasons are still unclear. There are seasonal factors like air and water temperatures, runoff and the

\section{它}


amount of precipitation, such as rain or snow, as well as the yearly different times of ice-break, and connected to this, the inflow of snowmelt. Generally, factors like climate, land use and anthropogenic input have been outlined. In addition, Klavins et al. stated the importance of wetlands in the river catchment, land usage type and runoff regime [8].

High-performance size-exclusion chromatography is extensively used for DOM characterisation and fractionation, because it is a non-destructive technique with well-known advantages $[9,11]$, that has been successfully applied in several studies by the present author [12, 13]. Usually, the most common wavelength used to detect separated DOM fractions is $254 \mathrm{~nm}$, but more studies nowadays apply multi-wavelength detection (diode array detection, (DAD)) [14]. Another means of gaining more information about DOM composition is to calculate the absorbance ratios at several wavelengths. In the present study, these ratios are named as optical/spectroscopic parameters. Several ratios have been found to serve as proxies for DOM compositional changes. The theoretical background is described in Yan et al.'s recent work [9].

The aim of the current work was to study the change of DOM parameters from natural water samples of Pirita River in Estonia during 2 years of winter-spring seasons, where the most drastic climate change occurs (temperature rises from -10 to $+15{ }^{\circ} \mathrm{C}$ ), using HPLC-SEC-DAD and ultraviolet-visible (UV-vis) spectroscopy.

\section{Experimental \\ Materials}

The present study includes water data from 2013 (nine samples) and 2014 (11 samples) during January to June, sampled from Pirita River in Tallinn, Estonia. Pirita River is a 105-km-long river, one of the largest in Estonia. It drains into Tallinn Bay (in the Gulf of Finland), in Pirita (a district of Tallinn). The catchment area is $794 \mathrm{~km}^{2}$, and its average flow is about $8 \mathrm{~m}^{3} \mathrm{~s}^{-1}$. The sampling point is located in the Pirita district, $4.9 \mathrm{~km}$ from the estuary $\left(59^{\circ} 27^{\prime} 58.73^{\prime \prime} \mathrm{N} 24^{\circ} 52^{\prime} 46.63^{\prime \prime} \mathrm{E}\right)$ [15]. The river level difference from the sea level is $5.98 \mathrm{~m}$. The list of the water samples, collected together with water, air temperature and water level data (retrieved from Estonian Hydrometeorological Institute) are shown in Table 1 [16]. Air and water temperatures and water level measurements are carried out directly on site. The water samples were stored at $4{ }^{\circ} \mathrm{C}$ in the dark. The average water $\mathrm{pH}$ in the spring is 7.8 , and organic compound and nutrient contents (ammonia and nitrates) are higher in the spring than in the summer. Respective data can be found in the literature [17].

\section{Methods}

\section{Chromatographic analysis}

Samples were filtered through $0.45-\mu \mathrm{m}$ Millipore filters before conducting the HPLC analysis. For this procedure,
Table 1 Hydrological data for Pirita River water samples

\begin{tabular}{rccc}
\hline Sampling date & \multicolumn{2}{c}{ Temperature, ${ }^{\circ} \mathrm{C}$} & \multicolumn{1}{c}{ Level, $\mathrm{cm}$} \\
\hline March 17, 2013 & Air & Water & \\
March 24, 2013 & -3.9 & 0.1 & 121.9 \\
March 31, 2013 & -0.6 & 0 & 109.2 \\
April 7, 2013 & 0.3 & 0 & 111.8 \\
April 14, 2013 & -0.9 & 0 & 114.9 \\
April 21, 2013 & 9 & 0.2 & 219.5 \\
April 28, 2013 & 8.1 & 5.6 & 190 \\
May 5, 2013 & 8.7 & 6.9 & 166 \\
May 12, 2013 & 14.5 & 9.4 & 137.4 \\
January 10, 2014 & 1.8 & 14.5 & 126.6 \\
January 22, 2014 & -10.8 & 4.2 & 146.1 \\
February 12, 2014 & 1.3 & 0.1 & 148 \\
March 13, 2014 & 1 & 0.2 & 200 \\
April 10, 2014 & -2 & 2.8 & 121.8 \\
April 28, 2014 & 14.1 & 4.2 & 115.6 \\
May 5, 2014 & 7.1 & 10.3 & 99.8 \\
May 12, 2014 & 13 & 3.9 & 84.6 \\
May 19, 2014 & 19.8 & 10.5 & 123.4 \\
May 26, 2014 & 18.9 & 13.6 & 117.3 \\
June 2, 2014 & 10.9 & 19 & 111.8 \\
\hline
\end{tabular}

a 20-mM phosphate buffer with $10 \%$ methanol ( $\mathrm{pH} 6.8)$ was used as a mobile phase for the HPLC-SEC system. HPLC measurements were carried out on BioSep-SEC-S 2000 size-exclusion column $(300 \times 7.8 \mathrm{~mm}$, Phenomenex $)$. The HPLC-SEC system was equipped with a multiwavelength absorbance detector, DAD (Agilent Technologies), and the chromatograms were registered on wavelengths between 200 and $600 \mathrm{~nm}$ using isocratic elution at

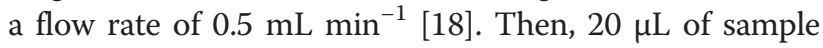
was injected for analysis. At least three replicates were carried out for each sample. All solutions for HPLC measurements were prepared using distilled water passed through a Milli-Q water purification system, filtered through $0.45-\mu \mathrm{m}$ pore size filters (Millipore) and degassed. The chromatograms were recorded and processed by Agilent ChemStation software.

The aliphatic fraction of DOM is not measured in our experiments because of the absence of conjugated double bonds, and thus, the obtained data represent only the UV-absorbing fraction. The registered chromatogram peak area at the selected wavelength (210, 254 and $280 \mathrm{~nm}$ ) corresponds to the relative quantity of DOM in a specific molecular size fraction that is not determined in the present study. The changes in the molecular structure were assessed following the changes in the retention times. Respectively, the peak with the lowest retention 
time refers to the highest molecular size fraction of DOM, and the peak with the highest retention time refers to the lowest molecular size fraction. Quantitative molecular properties of DOM were evaluated using a comparison of chromatographic parameters: $A_{\text {TOT210 }}$ (total peak area at $210 \mathrm{~nm}$ ), $A_{\text {Tот254 }}$ (total peak area at $254 \mathrm{~nm}$ ), $A_{\text {Tот280 }}$ (total peak area at $280 \mathrm{~nm}$ ), $A_{\text {PL210 }}$ (peptide-like components, peak area at $210 \mathrm{~nm}$ ) and ratio $A_{254} / A_{\text {PL210 }}$. Peak identification is carried out by extracting the UV-vis spectra of the chromatographic peak from the DAD data and comparing it with the existing database records of protein (bovine thyroglobulin, human gamma globulin, ovalbumin, myoglobin, uridine and tryptophan, Phenomenex), peptide, nitrate and humic substance (HS) (NOM, IHSS Nordic Reservoir 1R108N; HA, IHSS Nordic Aquatic 1R105H; FA, IHSS Nordic Aquatic 1R105F) standards. The total peak area recorded at $210 \mathrm{~nm}$ represents DOM (both humic and peptide-like constituents), and the total peak area recorded at 254 and $280 \mathrm{~nm}$ corresponds to the HS fraction of DOM. The peak at higher retention times is named peptide-like because the absorption spectra coincide with a 94-98\% probability with respective spectra of protein standards, but the molecular size is even smaller than that of HS. The UV spectrum of a peptide-like peak is characteristic for polypeptides (e.g. tripeptides). The peptide bonds found in the amino acids absorb at $205 \mathrm{~nm}$. The use of HPLC-SEC in studies of polypeptides of a molecular mass less than $5000 \mathrm{Da}$ is possible with a stationary phase used in column BioSep-SEC-S2000 [19] that enables excellent resolution in the molecular mass range from a few hundred to a few thousand Da. Peptides emerge from a column near the lower limit of the separation range.

\section{Spectroscopic analysis}

UV-vis absorption spectra were recorded using a UV-vis spectrophotometer (SPECORD 250 PLUS, Analytik Jena) with a wavelength area of $210-900 \mathrm{~nm}$ in a $1-\mathrm{cm}$ quartz cuvette. Milli-Q water served as a blank. Absorbances at several wavelengths $\left(A_{205}, A_{254}, A_{280}, A_{365}, A_{470}, A_{665}\right)$ and their ratios $\left(A_{254} / A_{205}, A_{365} / A_{470}, A_{470} / A_{665}\right)$ [9] were applied for the characterisation of the optical properties.

\section{Results and discussion}

\section{Chromatograms of water}

The objective of the present study is to apply HPLC-SEC in order to assess DOM changes as a function of climate change (water and air temperatures, water level). Therefore, the chromatographic analysis was made at three wavelengths $(210,254$ and $280 \mathrm{~nm}$ ) to study the DOM in more detail. The chromatogram of the water from January 10, 2014 at three wavelengths is presented in Fig. 1a. On the chromatogram registered at the wavelength of $210 \mathrm{~nm}$, two peaks are separated, one of which represents the HS fraction of DOM, and the other, peptide-like components of DOM. From the UV data registered, it is possible to extract a chromatogram at the selected wavelength, for example at $254 \mathrm{~nm}$, while also representing the results by drawing a contour graph in colour scale. Thus, in Fig. 1b, a contour graph (absorbance vs. retention time) of water from May 19, 2014 is shown. The chromatograms of Fig. 1c are similar to the chromatogram of Fig. 1a but for water samples taken at different times. However, in some samples from May to June 2014, two peptide-like peaks are detected, including a peak corresponding to a peptide-like-DOM complex, as revealed through the comparison of respective absorption spectra. The chromatograms registered at wavelengths of 254 and $280 \mathrm{~nm}$ of the water samples from May 19 (like others waters) consist only of HS peaks; however, at $210 \mathrm{~nm}$, the second peak represents the peptide-like-DOM complex, and the third corresponds to a peptide-like peak (Fig. 1c).

\section{Optical properties}

The absorption spectra of the studied water samples show a decrease of absorbance with increasing wavelengths, which is typical for DOM. Similar trends for absorbance (Fig. 2) are registered at wavelengths of 254, 280, 365 and $470 \mathrm{~nm}$, with the minimum occurring in February under an ice cover. At $205 \mathrm{~nm}$, more aliphatic and peptide-like DOM constituents together with some inorganic anions and carboxylic acids contribute, showing maximum values in January, with decreasing values thereafter. The absorbance at a wavelength of $254 \mathrm{~nm}\left(A_{254}\right)$ is often utilised as an indicator of DOM concentration, as well as the absorbance at $280 \mathrm{~nm}\left(A_{280}\right)$ [20]. An increase of well-humified organic matter $\left(A_{665}\right)$ in river water was detected after the spring floods in April.

Trends in absorbance ratios are different: The $A_{254} /$ $A_{205}$ ratio decreased in January thus reflecting the minimum number of DOM aromatic constituents in relation to the peptide-like substances of microbial origin that exhibited the maximum at the same time. The UV-vis absorbing functional groups ratio of DOM $\left(A_{365} / A_{470}\right)$ decreased slightly from 6 to 5 . The degree of the aromatic groups condensation of DOM $\left(A_{470} / A_{665}\right)$, or else degree of humification [20], decreased, with the exception of January and April. This absorbance ratio varied between 4 and 8 . This variation may be the result of dilution. The high values (up to 12) are explained by the presence of low molecular mass fulvic acids in the water [21]. The low values indicate input of DOM originating from the soil.

\section{Molecular properties}

The HPLC-SEC analysis of DOM resulted in HS, peptide-like, and in some samples, humic peptide-like 

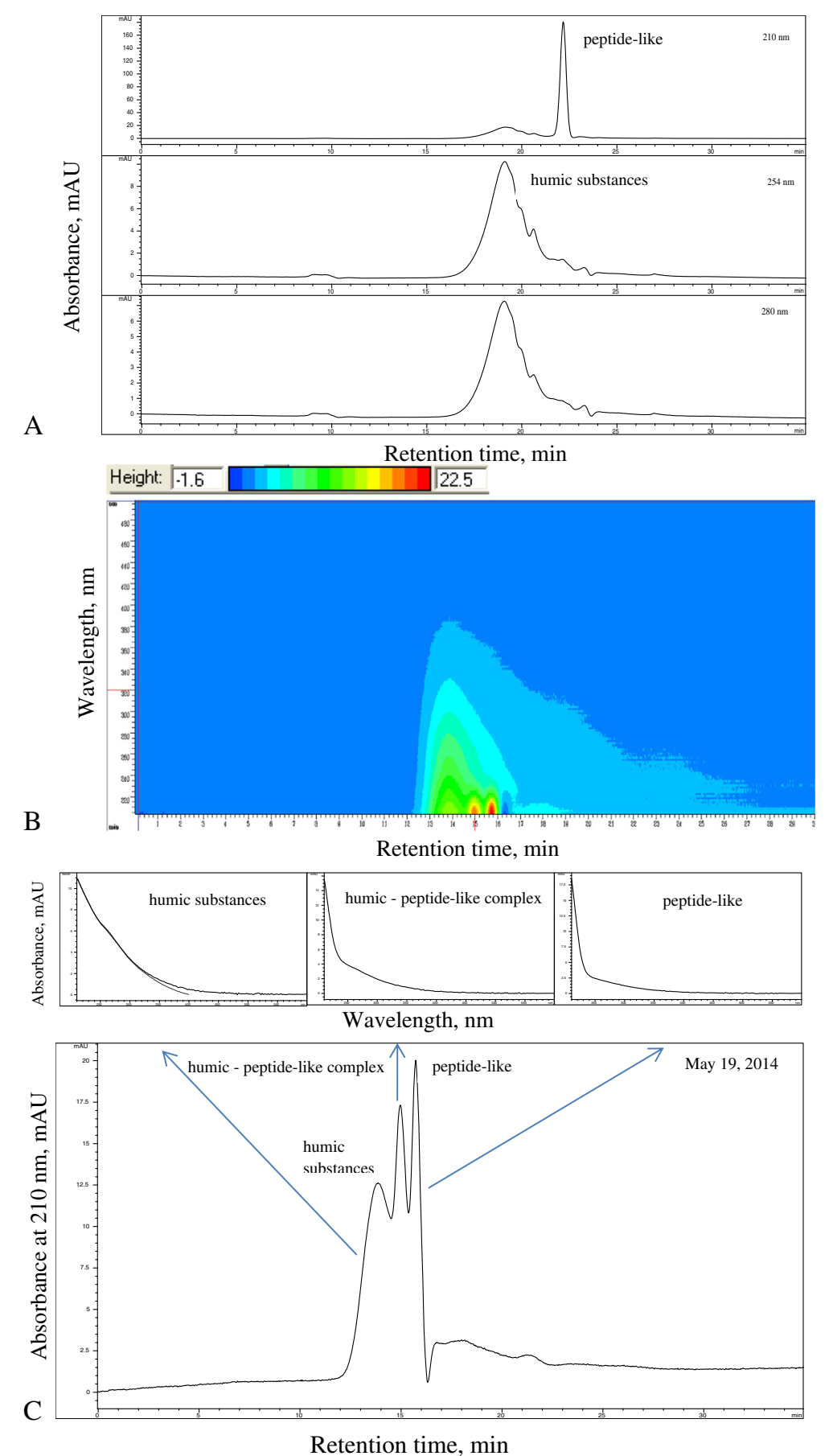

Fig. 1 Example of Pirita River water HPLC-SEC-DAD chromatograms: a detection at 210, 254 and 280 nm, sample from January 10, 2014; b contour plot, sample from May 19, 2014; and c chromatogram of sample (b) at $210 \mathrm{~nm}$ with separated DOM fractions and respective absorbance spectra

complexes. The incorporation of peptide-like fractions into humic structures is noticed in the May (2014) samples. It can be a weak association between DOM components, but in the present text, we refer to it as complex. In a recent study, protein-like and HS interactions were studied in detail, and supramolecular assemblies between those components are demonstrated for model solutions
[22]. Our results confirm the fluorescence spectroscopy results concerning DOM supramolecular structure in natural surface water, where component interactions are based on $\pi-\pi$ and/or van der Waals forces [23]. Integration of the chromatograms enables one to obtain the retention time for each peak, the area, the height and the identification of the substances, with comparisons 


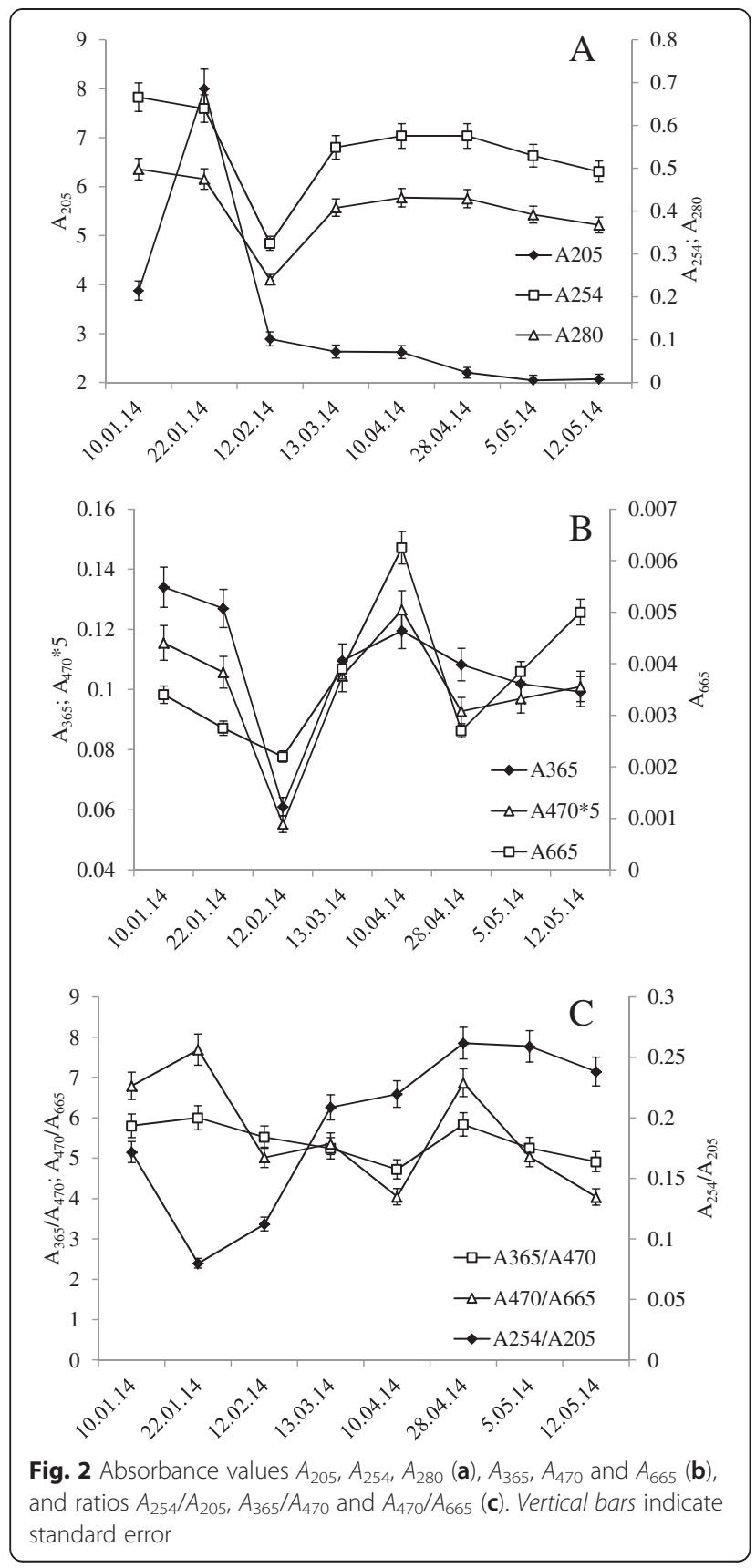

between the fraction spectrum and the standard spectrum. Total peak areas as estimates of relative quantity of respective fraction differed in the studied years, with an increase in April 2013 (Fig. 3a) and a decrease in April 2014 (Fig. $3 \mathrm{~b})$. The trends in absorbance ratio $A_{\mathrm{TOT} 254} / A_{\mathrm{PL} 210}$ (Fig. 3c) were similar from March to April, but different in winter (January to February) and in spring. This ratio makes possible to evaluate the relative content of $\mathrm{HS}$ and peptide-like components. Typical values are between 0.3 and 0.5 , and thus, peptide-like substances dominate two to three times over the HS in Pirita River water DOM.

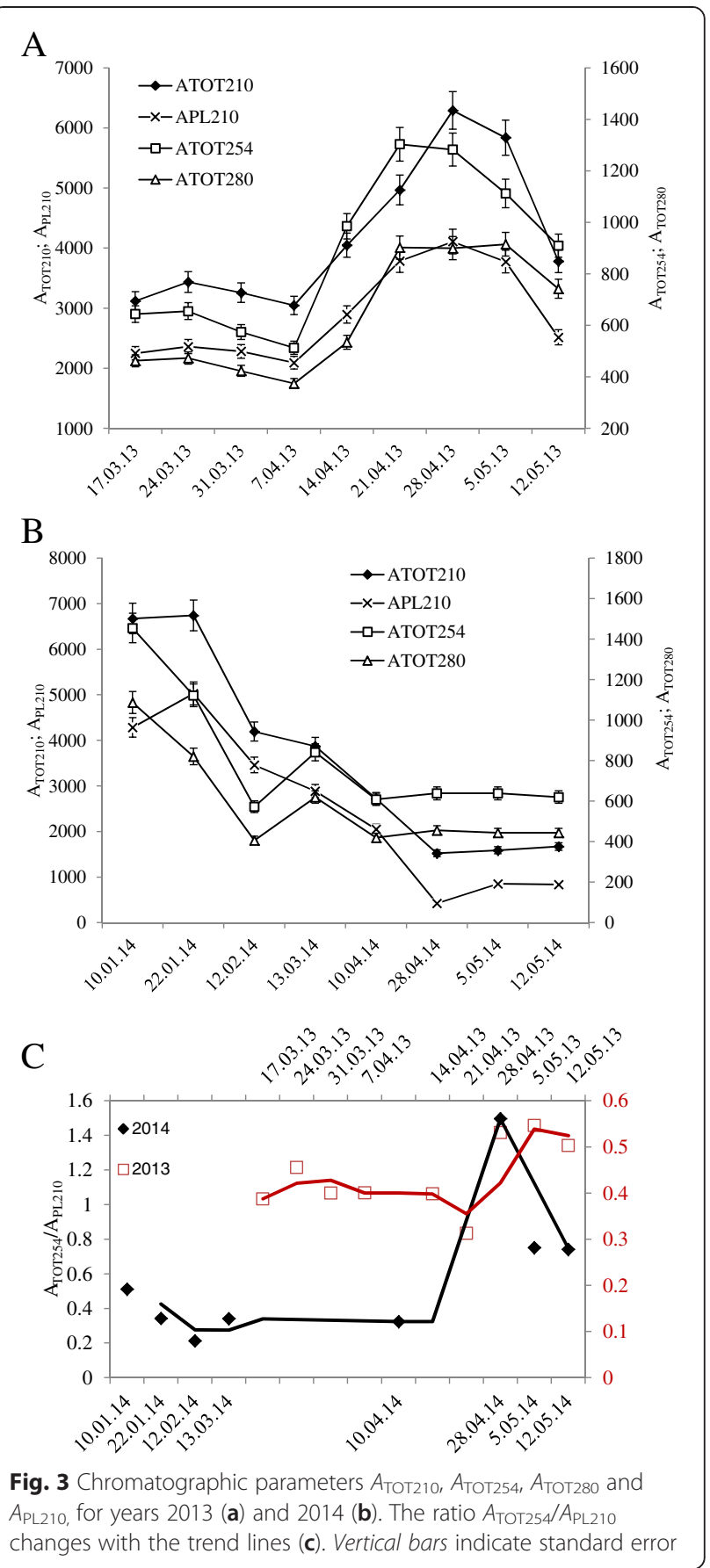

Only in one date did the HS dominate (ratio 1.5), and this could be caused by soil organic matter inflow.

\section{Effect of water and air temperatures}

Temperature effects on DOM characteristics were evaluated by studying how retention times and areas of different peaks change as a function of air and water temperatures. Air temperatures in 2013 (March to May) varied between -3.9 and $14.5{ }^{\circ} \mathrm{C}$ and in 2014 between -10.8 and $19.8^{\circ} \mathrm{C}$ (January to June) (Table 1 ). The long time 


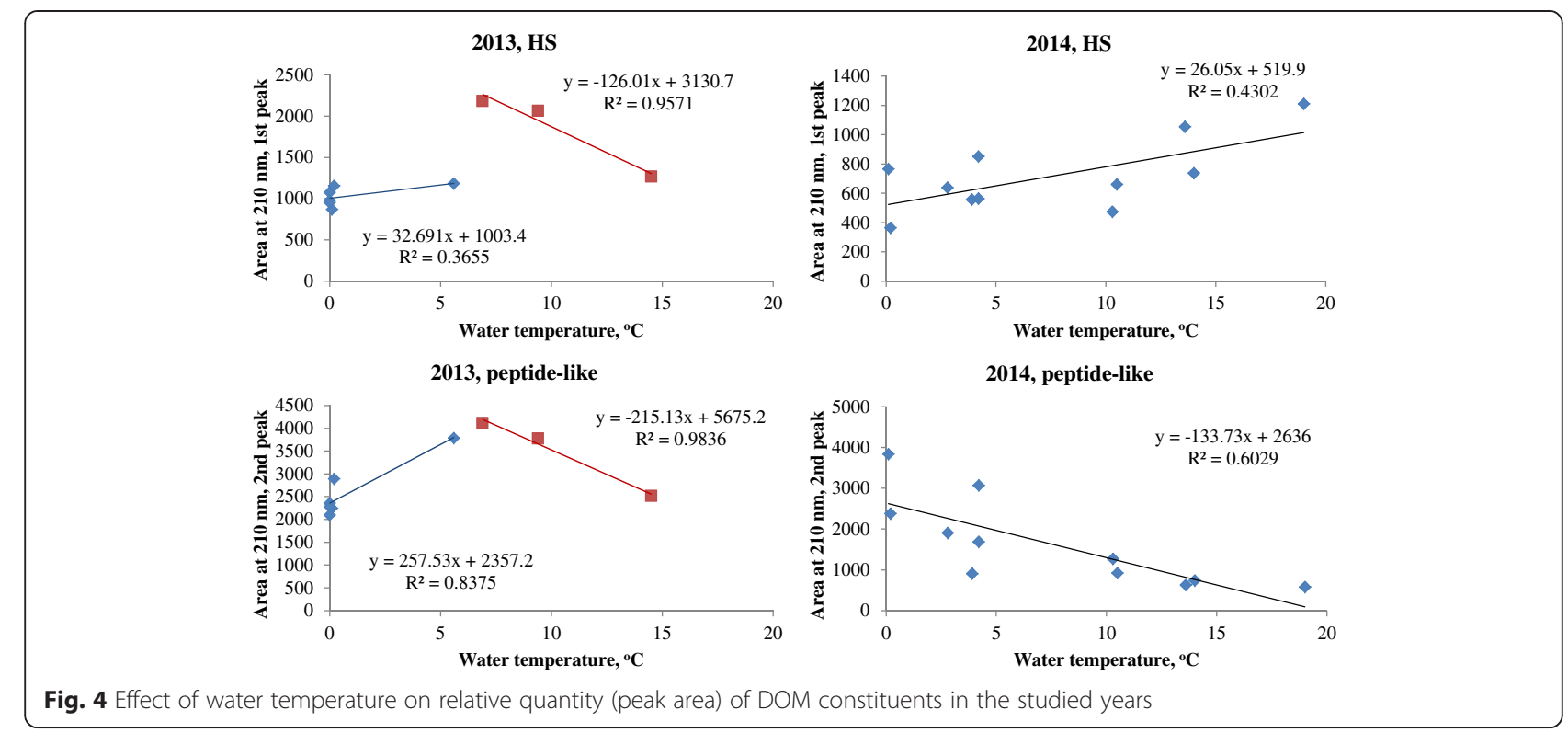

averages for the months of January to June are as follows: $-4.0,-4.7,-1.3,3.9,10.1$ and $13.2{ }^{\circ} \mathrm{C}$, respectively [16]. Water temperatures varied between 0 and $14.5{ }^{\circ} \mathrm{C}$ (2013) and between 0.1 and $19.0{ }^{\circ} \mathrm{C}$ (2014). In the 2014 samples, both water and air temperatures were highly correlated ( 0.89 and 0.75 , respectively) to UV ratio $A_{254} / A_{205}$. The increase of temperature caused increases of this ratio and constant decreases of peptidelike constituents in the water. Pirita River water is intensively coloured because of the high concentrations of HS originating from the catchment area. DOM sources are known to be marshlands and forests. During spring, usually, the snow melts, causing an increase of the water level, and DOM components from the soil are washed into the river water. This explains the increase of HS $\left(A_{254}\right)$. The increasing water temperature possibly causes a rise in the microbial activity, and thus, the relative content of peptide-like DOM components in water should decrease.

Chromatographic parameters for the year 2014 samples, $A_{\text {PL210, }} A_{\text {TOT254 }} / A_{\text {PL210, }}$, correlate quite well $(0.65-0.77)$ with water temperature and confirm in the spectroscopic results described above (Fig. 4). Water temperature increases caused decreases of peptide-like substances, but both HS $\left(A_{\text {TOT254 }}\right)$ and peptide-like substance $\left(A_{\text {PL210 }}\right)$ contents increased, together with the increasing air temperature, except for the data obtained at $-10{ }^{\circ} \mathrm{C}$. Our results indicate that water and air temperatures can have different effects on the peptide-like substance content in water.

The year 2013 samples show a very interesting temperature dependence; at low water temperatures $\left(0-6{ }^{\circ} \mathrm{C}\right)$, peptide-like substance $\left(A_{\mathrm{PL} 210}\right)$ concentrations increase, but at warmer climates $\left(7-15{ }^{\circ} \mathrm{C}\right)$, the opposite trend-a decrease-is obvious. A similar effect is noticed for $A_{\mathrm{TOT} 210}$ and $A_{\text {TOT280 }}$. We explain the results by assuming domination of DOM degradation processes in cold climates and enhanced microbial activity in warmer climate conditions. The increase of peptide-like components in water can also indicate an anthropogenic impact, like wastewater input [24].

\section{Effect of water level}

Water level increase is correlated with the studied absorbance values and ratios, and results in the decreasing of HS (Fig. 5a) and the increasing of the peptide-like

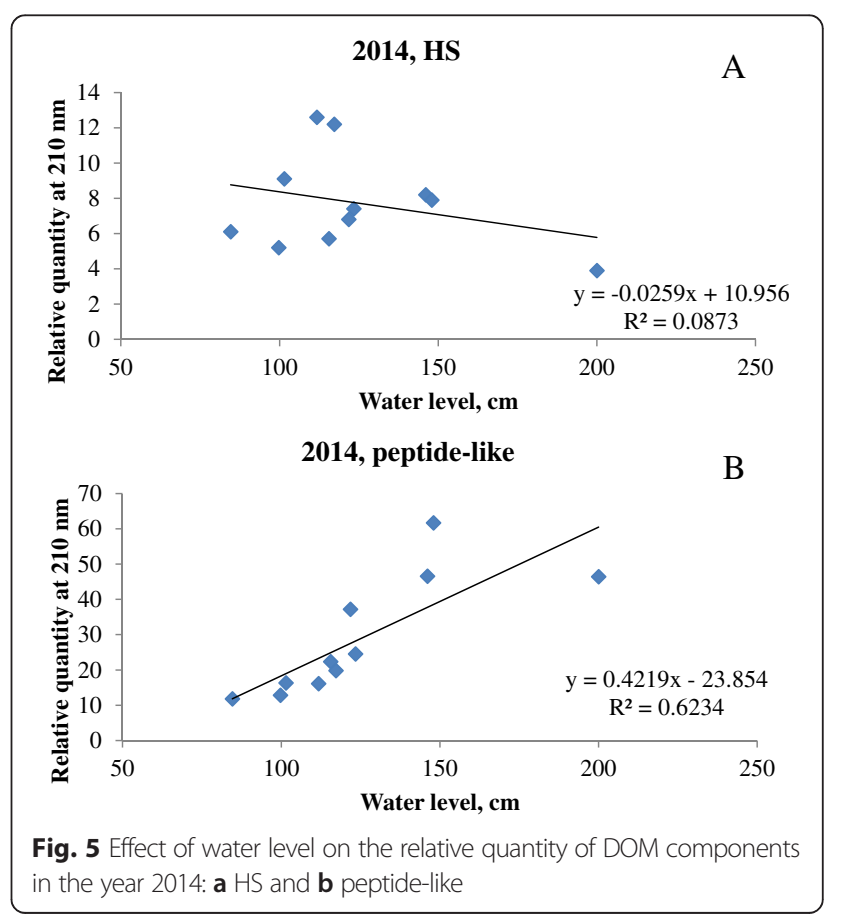


constituent (Fig. 5b). Again, input of snowmelt might carry DOM components preserved in soil water to the river, causing a dilution effect. The wastewater inflow, together with HS from the soil, can be a possible source for the increased content of the peptide-like substances. In 2001, the organic compounds that entered Pirita River were set in a self-purification process. The contents of organic compounds originating from sewage were minimal. The self-purification was due to the increase of the volume of water in the spring, which was very intensive and did not influence the microbiological quality of the water [17]. However, today, we cannot exclude the possible source of peptide-like substances from sewage and wastewater that are directed to the river water. Thus, the approach used in the present study, i.e. separation of humic and peptide-like DOM components based on molecular size, enables us to gain detailed information about chemical and compositional changes of organic matter in the water environment.

\section{Conclusions}

The results point out the usefulness of HPLC and UV-vis spectroscopy for studying DOM in relation to climate change. The methods used enabled detailed monitoring of humic molecules dissolved from the catchment soil, as well as microbial derivatives (peptide-like components of DOM). The new data obtained in the present study may help to clarify the role of humic molecules and peptidelike components of DOM on bioactivity changes due to the effects of temperature and water level. The approach used can be applied for monitoring changes in raw water quality, and thus, for the design and optimisation of drinking water process technology.

\section{Abbreviations}

DAD: diode array detection; DOC: dissolved organic carbon; DOM: dissolved organic matter; FA: fulvic acid; HA: humic acid; HPLC: high-performance liquid chromatography; HPLC-SEC: high-performance size-exclusion chromatography; HS: humic substances; NOM: natural organic matter; UV-vis: ultraviolet-visible.

\section{Competing interests}

The authors declare that they have no competing interests.

\section{Authors' contributions}

All of the authors contributed to the paper as follows. VL selected the research topic and planned the methods and experiments. LD, AV and KS carried out most of the experiments in the laboratory. $V L$ and LD were responsible for the data analysis and interpretation of the results. $V L$ wrote the paper. All of the authors approved the manuscript and agreed to its publication.

\section{Acknowledgements}

The authors are grateful to Dr. Tiiu Alliksaar (Institute of Geology, Tallinn University of Technology) for the kind permission to use the UV-vis spectrometer. Language was corrected by A. Shardell.

Received: 28 November 2014 Accepted: 4 June 2015

Published online: 23 June 2015

\section{References}

1. Lepane V (2012) HPLC fingerprints of porewater organic compounds as markers for environmental conditions. In: Young SS, Silvern SE (ed)
International Perspectives on Global Environmental Change. InTech, Rijeka, pp 311-328

2. Hejzlar J, Dubrovsky M, Buchtele J, Ružička M (2003) The apparent and potential effects of climate change on the inferred concentration of dissolved organic matter in a temperate stream (the Mališe River, South Bohemia). Sci Total Environ 310:143-152

3. Arvola L, Räike A, Kortelainen P, Järvinen M (2004) The effect of climate and landuse on TOC concentrations and loads in Finnish rivers. Boreal Env Res 9:381-387

4. Mattsson T, Kortelainen P, Räike A (2005) Export of DOM from boreal catchments: impacts of land use cover and climate. Biogeochemistry 76:373-394

5. Evans CD, Monteith DT, Cooper DM (2005) Long-term increases in surface water dissolved organic carbon: observations, possible causes and environmental impacts. Environ Pollut 137:55-71

6. Dawson JJC, Soulsby C, Tetzlaff D, Hrachowitz M, Dunn SM, Malcolm IA (2008) Influence of hydrology and seasonality on DOC exports from three contrasting upland catchments. Biogeochemistry 90:93-113

7. Piccolo A (2012) Carbon sequestration in agricultural soils: a multidisciplinary approach to innovative methods. Springer-Verlag, Berlin-Heidelberg

8. Klavins M, Kokorite I, Eglite L, Rodinov V (2012) Natural organic matter export from boreal catchments (the Salaca River basin, Latvia) and its influencing factors. Hydrology Research 43:330-340

9. Yan M, Korshin G, Wang D, Cai Z (2012) Characterization of dissolved organic matter using high-performance liquid chromatography (HPLC)-size exclusion chromatography (SEC) with a multiple wavelength absorbance detector. Chemosphere 87:879-885

10. Rodriguez-Murillo JC, Zobrist J, Filella M (2015) Temporal trends in organic carbon content in the main Swiss rivers, 1974-2010. Sci Total Environ 502:206-217

11. Chin YP, Aiken G, Oloughlin E (1994) Molecular-weight, polydispersity, and spectroscopic properties of aquatic humic substances. Environ Sci Technol 28:1853-1858

12. Lepane $V$, Kudrjašova M (2001) High-performance size exclusion chromatographic characterization of humic substances and dissolved organic matter from Baltic aquatic environment. Oil Shale 18:350-372

13. Lepane V, Leeben A, Malashenko O (2004) Characterization of sediment pore-water dissolved organic matter of lakes by high-performance size exclusion chromatography. Aquatic Sciences 66:185-194

14. Liu S, Lim M, Fabris R, Chow CWK, Drikas M, Korshin G, Amal R (2010) Multiwavelength spectroscopic and chromatography study on the photocatalytic oxidation of natural organic matter. Water Research 44:2525-2532

15. Map of River Pirita. https://www.google.ee/maps/@59.4646292,24.8548424, $2209 \mathrm{~m} /$ data=!3m1!1e3. Accessed 27 Nov 2014

16. Hydrology data. http://www.ilmateenistus.ee/siseveed/vaatlusandmed/tabel/. Accessed 25 Nov 2014

17. Rannamäe R, Veldre I (2001) Water quality in the Pirita River, a raw water source for Tallinn. Proc Estonian Acad Sci Biol Ecol 50:269-278

18. Lepane V, Tõnno I, Alliksaar T (2010) HPLC approach for revealing age-related changes of aquatic dissolved organic matter in sediment core. Procedia Chemistry 2:101-108

19. Irvine GB (2003) High-performance size-exclusion chromatography of peptides. Journal of Biochemical and Biophysical Methods 56:233-242

20. Kolic PE, Roy ED, White JR, Cook RL (2014) Spectroscopic measurements of estuarine dissolved organic matter dynamics during a large-scale Mississippi River flood diversion. Science of the Total Environment 485-486:518-527

21. Iljina SM, Drozdova OY, Lapitskiy SA, Alekhin YV, Demin W, ZavgorodnyayaYA SLS, Viers J, Pokrovsky OS (2014) Size fractionation and optical properties of dissolved organic matter in the continuum soil solution-bog-river and terminal lake of a boreal watershed. Org Geochem 66:14-24

22. Wang Z, Cao J, Meng F (2015) Interactions between protein-like and humic-like components in dissolved organic matter revealed by fluorescence quenching. Water Research 68:404-413

23. Piccolo A (2001) The supramolecular structure of humic substances. Soil Sci 166:810-832

24. Goldman JH, Rounds SA, Needoba JA (2012) Applications of fluorescence spectroscopy for predicting percent wastewater in an urban stream. Environ Sci Technol 46:4374-4381 